УДК 159.9.072.4

DOI https://doi.org/10.26661/2310-4368/2021-2-5

\title{
ПОКАЗНИКИ ПСИХОЛІНГВІСТИЧНОЇ КОМПЕТЕНТНОСТІ ТА ОСОБЛИВОСТІ ЗАГАЛЬНОЇ ТА ПРОФЕСІЙНОЇ МОТИВАЦІЇ СТУДЕНТІВ ЗВО
}

\author{
Бужинська С. М. \\ кандидат психологічних наук, дочент, \\ дочент кафедри педагогіки, психології, початкової освіти та освітнього менеджменту \\ К3 «Харківська гуманітарно-педагогічна академія» Харківської обласної ради \\ пров. Руставелі, 7, Харків, Украӥна \\ orcid.org/0000-0002-5103-0053 \\ svetlanakh314@gmail.com \\ Шукалова О. С. \\ кандидат психологічних наук, дочент, \\ доиент кафедри педагогіки, психології, початкової освіти та освітнього менеджменту \\ К3 «Харківська гуманітарно-педагогічна академія» Харківської обласної ради \\ пров. Руставелі, 7, Харків, Украӥна \\ orcid.org/0000-0002-5127-3987 \\ shukalova.o@gmail.com \\ Зайцева О. О. \\ викладач кафедри педагогіки, психології, початкової освіти та освітнього менеджменту \\ К3 «Харківська гуманітарно-педагогічна академія» Харківської обласної ради \\ пров. Руставелі, 7, Харків, Украӥна \\ orcid.org/0000-0001-8529-7269 \\ zaytseva1005@gmail.com
}

\begin{abstract}
Ключові слова: вміння слухати, вміння викладати думки, вміння переконувати, загальні мотиви, професійні мотиви, зовнішня мотивачія, внутрішня мотивація.
\end{abstract}

В умовах сьогодення, завданням закладів вищої освіти $є$ не тільки мотивація студентів на навчання та здобуття професійних знань, а й звернення уваги на методи навчання студентів, для яких здобуття професійних знань не $\epsilon$ мотивом лише отримання фінансового благополуччя, престижної роботи та визнання,а й можливістю донести свої переконання до оточуючих. Отже, метою дослідження було виявлення взаємозв'язку між психолінгвістичною компетентністю та загальною і професійною мотивацією.

У дослідженні взяли участь 307 студентів денної форми навчання першого, другого, третього і четвертого курсів у віці від 17 до 24 років. Емпіричне дослідження було здійснено за допомогою трьох груп психодіагностичних методик: методики, що виявляють рівень розвитку психолінгвістичної компетентності; методики, що націлені на діагностику загальних мотивів; методики, що націлені на діагностику професійних мотивів у студентів закладів вищоїосвіти. У дослідженні використані теоретичні методи логікопсихологічного аналізу: аналіз, синтез, узагальнення, систематизація, типологізація, моделювання; емпіричні: психодіагностичні методики; математико-статистичні: кореляційний аналіз.

Виявлено взаємозв'язок між психолінгвістичною компетентністю та більшістю досліджених мотивів. Встановлено, що показники психолінгвістичної компетентності пов’язані з такими мотиваційними 
особливостями, як високий рівень мотиву досягнення успіху та низький рівень мотиву уникнення невдач, високий рівень мотиву причетності та низький рівень мотиву запобігання знехтування, високий рівень внутрішніх мотивів та низький рівень зовнішніх мотивів. Визначено кореляційні зв'язки між показниками психолінгвістичної компетентності та такими мотиваційними особливостями як цікава, творча робота, отримання знань, оволодіння професією, соціальне значення труда та професійна майстерність. Встановлено, що показники психолінгвістичної компетентності «Вміння слухати», «Вміння викладати думки» та «Вміння переконувати» не корелюють 3 професійними мотивами, що сповільнюють особистісний розвиток студентів.

\title{
INDICATORS OF PSYCHOLINGUISTIC COMPETENCE AND FEATURES OF GENERAL AND PROFESSIONAL MOTIVATION OF STUDENTS OF HIGHER EDUCATION INSTITUTIONS
}

\author{
Buzhynska S. M. \\ Candidate of Psychological Sciences, Associate Professor, \\ Associate Professor at the Pedagogy, Psychology, Primary Education \\ and Educational Management Department \\ Municipal Establishment "Kharkiv Humanitarian Pedagogical Academy" \\ of Kharkiv Regional Council \\ Rustaveli Lane, 7, Kharkiv, Ukraine \\ orcid.org/0000-0002-5103-0053 \\ svetlanakh314@gmail.com \\ Shukalova O. S. \\ PhD, Associate Professor, \\ Associate Professor at the Pedagogy, Psychology, Primary Education \\ and Educational Management Department \\ Municipal Establishment "Kharkiv Humanitarian Pedagogical Academy" \\ of Kharkiv Regional Council \\ Rustaveli Lane, 7, Kharkiv, Ukraine \\ orcid.org/0000-0002-5127-3987 \\ shukalova.o@gmail.com
}

\author{
Zaitseva O. O. \\ Teacher of Pedagogy, Psychology, Primary Education and Educational Management Department \\ Municipal Establishment "Kharkiv Humanitarian Pedagogical Academy" \\ of Kharkiv Regional Council \\ Rustaveli Lane, 7, Kharkiv, Ukraine \\ orcid.org/0000-0001-8529-7269 \\ zaytseva1005@gmail.com
}

Key words: ability to listen, ability to express thoughts, ability to persuade, general motives, professional motives, external motivation, internal motivation.
In today's conditions, the task of higher education institutions is not only to motivate students to study and acquire professional knowledge, but also to pay attention to methods of teaching students, for whom the acquisition of professional knowledge is not only a motive for financial well-being, prestigious work and recognition, to give their beliefs to others. The aim of the 
study was to identify the relationship between psycholinguistic competence and general and professional motivation.

The study involved 307 full-time first, second, third and fourth year students aged 17 to 24 years. Empirical research was conducted using three groups of psychodiagnostic techniques: techniques that identify the level of development of psycholinguistic competence; techniques aimed at diagnosing common motives; methods aimed at diagnosing professional motives in students of higher education institutions. The study used theoretical methods of logical and psychological analysis: analysis, synthesis, generalization, systematization, typology, modeling; empirical: psychodiagnostic techniques; mathematical and statistical: correlation analysis.

The relationship between psycholinguistic competence and most of the studied motives is revealed. Indicators of psycholinguistic competence have been found to be associated with motivational characteristics such as a high level of motivation to succeed and a low level of motivation to avoid failure, a high level of motive for involvement and a low level of motivation to prevent neglect, high levels of internal motives and low levels of external motives. The correlations between indicators of psycholinguistic competence and such motivational features as interesting, creative work, knowledge acquisition, mastery of the profession, social significance of work and professional skill are determined. It is established that the indicators of psycholinguistic competence "Ability to listen", "Ability to teach thoughts" and "Ability to persuade" do not correlate with professional motives that slow down the personal development of students.

\section{Постановка проблеми}

В останні роки наша держава зазнає велику кількість змін - модернізація економічних, політичних, суспільних процесів. В даних умовах дуже важливим чинником успішної самореалізації молодого фахівця у соціумі $є$ професійна готовність. В умовах сьогодення, лише невелика кількість студентів в навчанні вмотивовані розвитком власної професії, суспільства та країни взагалі. Щоб збільшити кількість таких студентів, заклади вищої освіти мають звернути увагу на методи навчання студентів, для яких здобуття професійних знань не є мотивом лише отримання фінансового благополуччя, престижної роботи та визнання, а й можливістю донести свої переконання до оточуючих. Наявність впливу мотивації на успішність навчальної діяльності студентів було доведено великою кількістю вчених, але, щоб мати здатність мотивувати інших студентів, в них також повинна бути розвинена психолінгвістична компетентність, як «психолінгвістичний феномен, що дає можливість якісно, уміло та швидко регулювати психолінгвістичі процеси [5, с. 38]». Отже, з особливою актуальністю постає необхідність дослідження взаємозв'язку загальної та професійної мотивації з психолінгвістичною компетентністю студентів закладів вищої освіти.

Аналіз досліджень та публікацій.

Велика кількість іноземних та вітчизняних дослідників займалися вивченням психолінгвістичних процесів.
Одним 3 перших ідею пов'язати професійну мову 3 психологічними процесами в своїх роботах подає О. Леонтьєв. Він описав різні види і методи спілкування, 3 точки зору їх впливу на глибинні психологічні процеси людини. «Мовознавство, психологія мови і інші науки, які займаються промовою, оперують одними і тими ж індивідуальними об'єктами або подіями, отже, мають один і той же об'єкт науки [9; 10, с. 8].» Л. Виготський, також був одним з основоположників вітчизняної психолінгвістики. Автор подав ідею про те, що на психіку людини можна впливати за допомогою вербальних знакових систем. В своїх роботах він наполягав на тому, що на психологічну поведінку може впливати взаємозв'язок мислення і мови людини [3].

В своїй роботі, Г. Калмиков, завдяки емпіричному дослідженню, виділяє важливість розвитку психолінгвістичних процесів у студентів психологів. Він визначає, що «Зафіксований незадовільний стан розвитку професійно-мовленнєвої діяльності майбутніх психологів зумовлений недоліками існуючої системи підготовки психологів, яка залишається до цього часу не забезпеченою змістовно у психолінгвістичному відношенні» [8]. С. Серіков, в своїх наукових працях, також виділяє важливість вивчення та розвитку психолінгвістичних процесів. Автор зазначає, що можливість та вміння володіти словом та умінням слухати мову інших людей разом 3 когнітивним, створює необхідну передумову соціального життя людини [16]. 
Вивченням психолінгвістики займалися такі вчені як В. Белянін [2], О. Лурія [12], Т. Ушакова [17], В. Пищальникова [15], Е. Кабановская [7] тощо. Великий вклад у вивчення загальної та професійної мотивації зробили такі вчені як Дж. Аткінс [19], Д. Макклеланд [19], Х. Хекхаузен [18], А. Маслоу [14], О. Леонтьєв [11], О. Асмолов [1], М. Магомед-Емінов [13], Є. Ільїн [6], тощо. Незважаючи на велику кількість досліджень, питання взаємозв'язку психолінгвістичної компетентності з загальною та професійною мотивацією залишається відкритим.

Метою дослідження $\epsilon$ виявлення кореляційного зв'язку показників психолінгвістичної компетентності з загальними та професійними мотивами студентів.

\section{Виклад основного матеріалу дослідження}

У дослідженні взяли участь 307 студентів денної форми навчання першого, другого, третього і четвертого курсів у віці від 17 до 24 років.

Емпіричне дослідження було здійснено за допомогою трьох груп психодіагностичних методик:

Перша група - методики, що виявляють рівень розвитку психолінгвістичної компетентності («Вміння слухати», «Вміння висловлювати свої думки», «Вміння переконувати інших»);

Друга група - методики, що націлені на діагностику загальних мотивів: «Діагностика особливості на мотивацію до успіху» (Т. Елерс), «Діагностики особистості на мотивацію до уникнення невдач» (Т. Елерс), «Афіліації» (А. Мехрабіан), «Мотив влади», «Академічна саморегуляція» (Р. Райан, Д. Коннелл в адаптації М. Яцюка);

Третя група - методики, що націлені на діагностику професійних мотивів: «Мотиви вибору професії» (С. Груншпун), «Мотивація навчання у 3ВО» (Т. Ільїна), «Професійна мотивація».

В процесі статистичної обробки отриманих результатів було здійснено кореляційний аналіз показників психолінгвістичної компетентності 3 загальними та професійними мотивами студентів вищих навчальних закладів.

Було проведено кореляційний аналіз оцінок досліджуваних за методиками «Вміння слухати», «Вміння висловлювати свої думки», «Вміння переконувати інших», як показниками психолінгвістичної компетентності 3 показниками рівнів загальних мотивів (за методиками «Діагностика особливості на мотивацію до успіху», «Діагностики особистості на мотивацію до уникнення невдач», «Афіліації», «Мотив влади», «Академічна саморегуляція»), дані наведені у табл. 1 .

Результати, наведені у табл. 1, показують, що показник психолінгвістичної компетентності «Вміння слухати» утворив статистично значущі кореляційні зв'язки із більшістю оцінок загальних мотивів (досягнення успіху, уникнення невдачі, причетності, запобігання знехтування, влади, ідентифікованого регулювання, власного спонукання).

Прямий взаємозв'язок з показником «Вміння слухати» утворили такі загальні мотиви як мотив досягнення успіху та уникнення невдачі, мотив причетності та запобігання знехтування, ідентифікованого регулювання та власного спонукання. Отже, чим вище у студентів бажання досягти успіху в навчанні, чи у будь якій іншій діяльності та бажання бути частиною соціальної групи, тим більше розвинене у них вміння виділяти з тексту, який вони прослуховують, тільки важливі для себе і наповнені змістом окремі слова або фрази. Такий зв'язок може виникати тому, що студенти, які бажають бути успішними, досягати своєї мети за будь яких умов, можуть виділяти інформативну, важливу для них інформацію з тексту, який був прослуханий та використовувати їі для досягнення цієї мети. Також, вміння слухати інших, дуже важливо в соціалізації студентів. Плідне спілкування з людьми можливе лише за умов взаєморозуміння, а взаєморозуміння не можливе без уміння почути співрозмовника та виділити важливу інформацію з його мовлення.

Таблиця 1

Взаємозв'язок показників психолінгвістичної компетентності із загальними мотивами

\begin{tabular}{|c|c|c|c|c|c|c|}
\hline \multirow{3}{*}{ Загальні мотиви } & \multicolumn{6}{|c|}{ Показники психолінгвістичної компетентності } \\
\hline & \multicolumn{2}{|c|}{ Вміння слухати } & \multicolumn{2}{|c|}{ Вміння викладати думки } & \multicolumn{2}{|c|}{ Вміння переконувати } \\
\hline & $r_{x y}$ & $\mathbf{p}$ & $r_{x y}$ & $\mathbf{p}$ & $r_{x y}$ & $\mathbf{p}$ \\
\hline Досягнення успіху & 0,342 & $<0,01$ & 0,264 & $<0,01$ & 0,321 & $<0,01$ \\
\hline Уникнення невдачі & 0,121 & $<0,05$ & $-0,112$ & $<0,05$ & 0,036 & $>0,05$ \\
\hline Причетності & 0,167 & $<0,01$ & 0,274 & $<0,01$ & 0,411 & $<0,01$ \\
\hline Запобігання знехтування & 0,434 & $<0,01$ & 0,043 & $>0,05$ & 0,023 & $>0,05$ \\
\hline Влади & $-0,282$ & $<0,01$ & 0,193 & $<0,05$ & 0,231 & $<0,01$ \\
\hline Зовнішнє регулювання & 0,087 & $>0,05$ & $-0,112$ & $<0,05$ & 0,092 & $>0,05$ \\
\hline Інтроектоване регулювання & 0,005 & $>0,05$ & $-0,250$ & $<0,01$ & 0,011 & $>0,05$ \\
\hline Ідентифіковане регулювання & 0,388 & $<0,01$ & 0,189 & $<0,01$ & 0,241 & $<0,01$ \\
\hline Власне спонукання & 0,270 & $<0,01$ & 0,132 & $<0,05$ & 0,439 & $<0,01$ \\
\hline
\end{tabular}


Очікуваним є кореляційний зв'язок внутрішньої мотивації (ідентифіковане регулювання, власне спонукання) 3 показником психолінгвістичної компетентності «Вміння слухати». Таким чином, чим більше студенти керовані власними мотивами, тим більше в них розвинене вміння якісно обирати інформацію до якої вони прислухаються. Даний зв'язок може виникати тому, що людина, яка звикла дотримуватися лише власного вибору, мотивована тільки своїми бажаннями та цілями вміє виділити з прослуханої інформації лише таку, що може бути корисною.

Показник психолінгвістичної компетентності «Вміння слухати», очікувано показав зворотній кореляційний зв'язок з мотивом влади. Отже, чим більше людина керована жагою до влади, тим менше вона прислухається до інформації, що йде від оточуючих. Такий взаємозв'язок, можна пояснити тим, що людина вмотивована лише бажанням лідерства та керуванням іншими, вважає, що не має потреби в порадах оточуючих. Тобто, інформація, яку дають оточуючі не має для даної людини інформативної цінності і прислухатися до неї вона не бачить сенсу.

Наведені в табл. 1 результати, дають можливість побачити, що показник психолінгвістичної компетентності «Вміння викладати думки» утворив статистично значущі кореляційні зв'язки із більшістю оцінок загальних мотивів (досягнення успіху, уникнення невдачі, причетності, влади, зовнішнього регулювання, інтроектованого регулювання, ідентифікованого регулювання, власного спонукання).

Статистично значущій прямий взаємозв'язок iз показником «Вміння викладати думки» встановили оцінки мотиву досягнення успіху, мотиву причетності, мотиву влади, ідентифікованого регулювання та власного спонукання. Отже, чим вище у студентів бажання досягти успіху в навчанні, чи у будь якій іншій діяльності, бажання бути частиною соціальної групи та вміння керуватися тільки власними ідеями та думками, тим більше розвинене в них вміння донести до оточуючих конкретну ідею або власну думку. Такий зв'язок може виникати тому, що студенти, які керовані прагненням досягти поставленої задачі, спрямовані на досягнення успіху в поставлених цілях та мають бажання бути причетними до соціальних груп, найчастіше, вміють формулювати свої думки таким чином, щоб донести до людей саме ту ідею чи думку, що було задумано. Також, вміння правильно донести свої думки до оточуючих, притаманне людям 3 високим рівнем мотиву влади, бо лідерство та керування людьми завжди передбачає здатність говорити так, щоб тебе почули.

Зворотній кореляційний зв'язок, очікувано, утворили показник психолінгвістичної компетент- ності «Вміння викладати думки» 3 мотивом уникнення невдачі та зовнішніми мотивами (зовнішне регулювання, інтроектоване регулювання). Таким чином, чим більше у студентів страх до невдачі та бажання іiі уникнути, чим більше вони вмотивовані думками та порадами оточуючих, тим менше їх здатність викладати свої думки так, щоб донести ïx до інших людей. Даний зв'язок може виникати тому, що студенти, керовані страхом перед невдачею та дотримуються тільки порад інших, мають страх висловлювати свої думки і тому не здатні формулювати їх так, щоб донести до слухачів.

Результати, наведені у табл. 1, показують наявність прямого статистично значущого кореляційного зв'язку показника психолінгвістичної компетентності «Вміння переконувати» із оцінками мотивів досягнення успіху, причетності, влади, ідентифікованого регулювання та власного спонукання. Отже, чим більше у студента бажання досягти успіху, бути причетним до соціальних груп та стати їх лідером, чим більше він керується своїми власними бажаннями та думками, тим більш вміло він залучає оточуючих прийняти свої ідеї та слідувати за ним. Такий кореляційний зв'язок можна пояснити тим, що студенти, які прагнуть досягти поставленої мети, яку вони самі для себе визначили, та мають мотиваційну спрямованість на досягнення успіху в поставлених завданнях, керовані жагою до влади, бажанням лідерства та контролюванням людей, повинні вміти зацікавити слухачів та схилити їх прийняти свої ідеї.

Було проведено кореляційний аналіз оцінок досліджуваних за методиками «Вміння слухати», «Вміння висловлювати свої думки», «Вміння переконувати інших», як показниками психолінгвістичної компетентності з показниками рівнів професійних мотивів (в часовій трансспективі) (за методиками «Мотиви вибору професії» (ретроспективний аспект), «Мотивація навчання у 3ВО» (актуальний аспект), «Професійна мотивація» (потенційний аспект), дані наведені у табл. 2.

Результати статистичного аналізу, наведені в табл. 2, очікувано, показали прямий кореляційний зв' язок показників психолінгвістичної компетентності «Вміння слухати», «Вміння викладати думки» та «Вміння переконувати» 3 оцінками професійного мотиву прагнення творчої роботи (мотив вибору професії). Отже, чим вище в студента прагнення отримати цікаву, творчу роботу, тим краще в нього розвинене уміння обирати 3 усього почутого конкретно ту інформацію, що йому потрібна та здатність висловлювати свої думки таким чином, щоб його почули. Такий зв'язок може виникати тому, що студенти, які обирають професію за її цікавість, змогу творчого розвитку, можливість принести в цей світ щось нове та потрібне, мають здатність формулювати свої 
Таблиця 2

Взаємозв'язок показників психолінгвістичної компетентності

із показниками професійних мотивів (в часовій трансспективі)

\begin{tabular}{|c|c|c|c|c|c|c|c|}
\hline \multirow{3}{*}{\multicolumn{2}{|c|}{ Професійні мотиви (в часовій трансспективі) }} & \multicolumn{6}{|c|}{ Показники психолінгвістичної компетентності } \\
\hline & & \multicolumn{2}{|c|}{ Вміння слухати } & \multicolumn{2}{|c|}{$\begin{array}{c}\text { Вміння } \\
\text { викладати } \\
\text { думки } \\
\end{array}$} & \multicolumn{2}{|c|}{$\begin{array}{c}\text { Вміння } \\
\text { переконувати }\end{array}$} \\
\hline & & $r_{x y}$ & $\mathbf{p}$ & $r_{x y}$ & $\mathbf{p}$ & $r_{x y}$ & $\mathbf{p}$ \\
\hline \multirow{3}{*}{$\begin{array}{c}\text { Вибору професії } \\
\text { (ретроспективний } \\
\text { аспект) }\end{array}$} & Мотив вибору престижної професії & 0,051 & $>0,05$ & 0,012 & $>0,05$ & 0,005 & $>0,05$ \\
\hline & Мотив вибору матеріальних благ & 0,012 & $>0,05$ & 0,087 & $>0,05$ & 0,114 & $>0,05$ \\
\hline & Мотив прагнення творчої роботи & 0,293 & $<0,01$ & 0,234 & $<0,01$ & 0,224 & $<0,01$ \\
\hline \multirow{3}{*}{$\begin{array}{c}\text { Навчання в 3ВО } \\
\text { (актуальний } \\
\text { аспект) }\end{array}$} & Мотив придбання з1 & 0,434 & $<0,01$ & 0,239 & $<0,01$ & $-0,264$ & $<0,01$ \\
\hline & Мотив оволодіння професією & 0,282 & $<0,01$ & 0,193 & $<0,05$ & $-0,167$ & $<0,01$ \\
\hline & Мотив отримання диплома & 0,012 & $>0,05$ & 0,112 & $>0,05$ & 0,031 & $>0,05$ \\
\hline \multirow{4}{*}{$\begin{array}{c}\text { Професійної } \\
\text { діяльності } \\
\text { (потенційний } \\
\text { аспект) }\end{array}$} & Мотив власної праці & 0,015 & $>0,05$ & 0,092 & $>0,05$ & 0,012 & $>0,05$ \\
\hline & Мотив соціальної значущості праці & 0,483 & $<0,01$ & 0,396 & $<0,01$ & 0,345 & $<0,01$ \\
\hline & Мотив самоствердження у праці & 0,031 & $>0,05$ & 0,012 & $>0,05$ & 0,087 & $>0,05$ \\
\hline & Мотив професійної майстерності & 0,213 & $<0,01$ & 0,226 & $<0,01$ & 0,271 & $<0,01$ \\
\hline
\end{tabular}

думки таким чином, щоб бути почутими іншими та передати свої думки та ідеї оточуючим. Також, такі студенти вміють чути та виділяти 3 почутої інформації важливі для себе та наповнені сенсом слова чи окремі фрази, що можуть бути корисними для рішення певної проблеми чи досягнення поставленої мети.

Наведені в табл. 2 результати, дають можливість побачити, що показники психолінгвістичної компетентності «Вміння слухати», «Вміння викладати думки» та «Вміння переконувати» утворили статистично значущі прямі взаємозв'язки 3 оцінками професійного мотиву придбання знать та професійного мотиву оволодіння професією (мотиви навчання в 3ВО). Таким чином, чим вище в студентів бажання отримати знання та професійну компетентність під час навчання, тим краще в них розвинена змога зрозуміло викладати свої думки, викликати цікавість до них в оточуючих, а також відокремлювати потрібну інформацію від усього почутого. Такий кореляційний зв'язок можна пояснити тим, що студенти, які вчаться в закладі вищої освіти заради отримання знань, які вони зможуть використовувати в своїй професіональній кар'єрі, для яких професійні уміння мають більше значення, ніж просто наявність диплома, вміють, з почутого тексту, відокремити важливу для них інформацію, від тої, що не має значення та непотрібна на даний момент для рішення певної поставленої проблеми. Також, такі студенти вміють привернути увагу оточуючих своїми промовами, зацікавити слухачів та схилити їх прийняти свої ідеї та думки.

Результати, наведені у табл. 2 , показують наявність прямого статистично значущого кореляційного зв'язку показників психолінгвістичної компетентності «Вміння слухати», «Вміння викладати думки» та «Вміння переконувати» 3 оцінками професійного мотиву соціальної значущості праці та професійного мотиву професійної майстерності (мотив професійної діяльності). Отже, чим більше студента цікавить соціальна значущість обраної професії та рівень власної майстерності в обраній спеціальності, тим вище його вміння виділяти 3 тексту, який він прослуховує, важливі для себе і наповнені змістом слова, а також доносити до оточуючих конкретну ідею або власну думку. Даний взаємозв'язок можна пояснити тим, що студенти, для яких обрана професія $є$ не тільки шляхом самоствердження, фінансового благополуччя та визнання, а засобом розвитку своєї спеціальності та суспільства взагалі, найчастіше, вміють правильно донести свої думки до оточуючих, переконати їх у правильності своїх ідей та вислухавши промови інших, відокремити потрібні для саморозвитку та розвитку власної професії слова, фрази чи навіть ідеї.

Висновки. У результаті дослідження виявлено взаємозв'язок між психолінгвістичною компетентністю та більшістю досліджених мотивів. Аналіз отриманих даних дозволяє дійти таких висновків:

- показники психолінгвістичної компетентності пов'язані з такими мотиваційними особливостями, як високий рівень мотиву досягнення успіху та низький рівень мотиву уникнення невдач, високий рівень мотиву причетності та низький рівень мотиву запобігання знехтування, високий рівень внутрішніх мотивів та низький рівень зовнішніх мотивів;

- 3 показниками психолінгвістичної компетентності пов'язані такі мотиваційні особливості як цікава, творча робота, отримання знань, оволодіння професією, соціальне значення труда та професійна майстерність. 


\section{ЛITЕРАТУРА}

1. Асмолов А. Г. Психология личности : Учебник. Москва : МГУ, 1990. 367 с.

2. Белянин В. П. Введение в психолингвистику. Москва : ЧеРо, 1999. 128 с.

3. Выготский Л. С. Мышление и речь. Москва : Лабиринт, 2001. 368 с.

4. Зайцева О. О. Мотиваційні чинники розвитку метакогнітивної активності у структурі академічної саморегуляції студентів: дис. 053. Харків, 2020. 228 с.

5. Ильин Е. П. Мотивация и мотивы : учебное пособие. Санкт-Петербург : Питер, 2002. 512 с.

6. Кабановская Е. Ю. Изучение вербальних ассоциаций в психолингвистике. Символ науки: международный научный журнал. 2020. № 5. С. 139-140.

7. Калмиков Г. В. Передумови розвитку професійномовленнєвої діяльності майбутніх психологів. Зб. наук. праць ДВНЗ «Переяслав-Хмельницький державний педагогічний університет імені Григорія Сковороди» 2016. № 19/1. С 71-83.

8. Леонтьев А. А. Основы психолингвистики. Москва : Смысл, 2003. 287 с.

9. Леонтьев А. А. Психолингвистические единицы и порождение речевого высказывания. Москва : Наука, 1969. 307 с.

10. Леонтьев А. Н. Потребности, мотивы и эмоции. Москва : Изд-во. Моск. ун-та, 1971. с. 13-39.

11. Лурия А. Р. Основные проблемы нейролингвистики. Москва : МГУ, 1975.

12. Магомед-Эминов М. Ш., Васильев И.А. Мотивация и контроль за действием. Москва : МГУ, 1991. $144 \mathrm{c}$.

13. Маслоу А. Г. Мотивация и личность. Санкт-Петербург : Евразия, 1999. 478 с.

14. Пищальникова В.А. История и теорія психолингвистики. Монография. Мостьл. Журнал переводчиков. 2020. № 4 (68). С. 76-78.

15. Серіков В. В. Педагогічна майстерність викладача вищого навчального закладу: психолінгвістичний вимір. Зб. наук. пращь ДВНЗ «Переяслав-Хмельнищький державний педагогічний університет імені Григорія Сковороди» 2016. № 19/1. С 160-173.

16. Ушакова Т.Н. Психолингвистика : учебник для вузов. Москва : Пер Сэ, 2006. 415 с.

17. Хекхаузен Х. Психология мотивации достижения : учебн. пособ. Санкт-Петербург : Речь, 2001. $240 \mathrm{c}$.

18. McClelland D.C., Atkinson J.W. Methods of measuring human. Motives in fantasy, action and society. Princeton (NJ) : Van Nostrand, 1958. pp. 7-42.

\section{REFERENCES}

1. Asmolov A. G. (1990) Psikhologiya lichnosti : Uchebnik [Personality Psychology: Textbook]. Moscow: MGU. (in Russian)

2. Belyanin V. P. (1999) Vvedenie v psikholingvistiku [Introduction to psycholinguistics]. Moscow: CheRo. (in Russian)

3. Vy`gotskij L. S. (2001) My 'shlenie i rech '[Thinking and speech]. Moscow: Labirint. (in Russian)

4. Zaitseva O. O. (2020) Motyvatsiini chynnyky rozvytku metakohnityvnoi aktyvnosti u strukturi akademichnoi samorehuliatsii studentiv [Motivational factors of metacognitive activity development in the structure of students' academic self-regulation] (PhD dys.) Kharkiv

5. Il'in E. P. (2002) Motivacziya i motivy`: uchebnoe posobie [Motivation and motives: a textbook]. St. Petersburg: Peter. (in Russian)

6. Kabanovskaia E. Yu. (2020) Yzuchenye verbalnykh assotsyatsyi v psykholynhvystyke. [Study of verbal associations in psycholinguistics]. Symbol of science: an international scientific journal, vol. 5. pp. 139-140.

7. Kalmykov H. V. (2016) Peredumovy rozvytku profesiinomovlennievoi diialnosti maibutnikh psykholohiv [Prerequisites for the development of professional speech activities of future psychologists]. Coll. Science. Proceedings of «Pereyaslav-Khmelnytsky State Pedagogical University named after Hryhoriy Skovoroda», vol. 19, no. 1, pp. 71-83.

8. Leont'ev A. A. (2003) Osnovy` psikholingvistiki [The basics of psychoellinguistics]. Moscow: Smysl. (in Russian)

9. Leont'ev A. A. (1969) Psikholingvisticheskie ediniczy' $i$ porozhdenie rechevogo vy'skazy vaniya [Psycholinguistic units and the generation of speech utterance]. Moscow: Nauka. (in Russian)

10. Leont`ev A. N. (1971) Potrebnosti, motivy`i e’moczii. [Needs, motives and emotions]. Moscow: Mosk. un-ta, pp. 13-39. (in Russian)

11. Luriya A. R. (1975) Osnovny'e problemy' nejrolingvistiki [The main problems of neurolinguistics]. Moscow: MGU. (in Russian) 
12. Magomed-E`minov M. Sh., Vasil’ev I.A. (1991) Motivacziya i kontrol’ za dejstviem [Motivation and control over action]. Moscow: MGU. (in Russian)

13. Maslou A. G. (1999) Motivacziya i lichnost ' [Motivation and personality]. St. Petersburg : Evraziya. (in Russian)

14. Pyshchalnykova V.A. (2020) Ystoryia y teoriia psykholynhvystyky [History and theory of psycholinguistics]. Monograph. Bridges. Journal of Translators. vol. 4, no. 68, pp. 76-78.

15. Serikov V. V. Pedahohichna maisternist vykladacha vyshchoho navchalnoho zakladu: psykholinhvistychnyi vymir [Pedagogical skill of a higher education teacher: psycholinguistic dimension]. Coll. Science. Proceedings of «Pereyaslav-Khmelnytsky State Pedagogical University named after Hryhoriy Skovoroda», vol. 19, no. 1, pp. 160-173.

16. Ushakova T.N. (2006) Psikholingvistika : uchebnik dlya vuzov [Psycholinguistics: a textbook for universities]. Moscow: Per Se. (in Russian)

17. Khekkhauzen X. (2001) Psikhologiya motivaczii dostizheniya : uchebn. posob [Psychology of achievement motivation: textbook. allowance.]. St. Petersburg: Rech. (in Russian)

18. McClelland D.C., Atkinson J.W. (1958) Methods of measuring human. Motives in fantasy, action and society. Princeton (NJ) : Van Nostrand 